\title{
KENAIKAN BERAT BADAN BAYI DENGAN BERAT BADAN LAHIR RENDAH (BBLR) MELALUI PELAKSANAAN PERAWATAN METODE KANGURU (PMK) DI RUMAH
}

\author{
Samuel Maju Simanjuntak르, Dina Hartini² \\ 1 Universitas Advent IndonesiaJl. Kol. Masturi No.288, Kec. Parongpong, Kab. Bandung Barat, 40559 \\ 2Stikes Jendral Ahmad Yani CimahiJl. Terusan Jenderal Sudirman Cimahi - 40633 \\ Email: smsimanjuntak@unai.co.id
}

\begin{abstract}
Abstrak
Angka kematian bayi BBLR di Indonesia masih tinggi khususnya di Jawa Barat. Penelitian ini bertujuan untuk mengetahui pengalaman ibu dalam pelaksanaan PMK dirumah terhadap BBLR pasca rawat inap, serta hubungannya dengan kenaikan berat badan bayi. Penelitian ini menggunakan metode deskriptif kuantitatif. Data dianalisa dengan menggunakan uji statistik Spearman's rho test. Populasi pada penelitian ini adalah semua ibu yang memiliki bayi BBLR yang telah pulang dari RSUD Soreang pulang. Metode sampling yang digunakan adalah non probability sampling dengan jumlah sampel adalah 30 orang ibu beserta bayinya. Hasil penelitian menunjukkan pelaksanaan perawatan metode kanguru di rumah adalah ditunjukkan dengan persentase yang masih rendah (10\%). PMK berkorelasi denagn peningkatkan berat badan BBLR36,7\% dengan $p$ value 0,046.

Kata kunci : bayi BBLR; pelaksanaan PMK di rumah; kenaikan berat badan.

Abstract

LBW infant mortality rates in Indonesia are still high, especially in West Java. This study was aimed to determine the experience of mothers in the implementation of Kangaroo Mother Care at home to LBW after hospitalization, as well as its relationship with infant weight gain. This research used quantitative descriptive methods. Data were analysed using the Spearman's rho statistical test. The population in this study were all mothers with LBW babies who had returned from Soreang District Hospital. The sampling method used was non-probability sampling with the number of samples is 30 mothers and their babies. The results showed that the implementation of kangaroo treatment at home was indicated by a low percentage (10\%). Kangaroo Mother Care correlated with increasing LBW weight by $36.7 \%$ with p-value 0.046 .
\end{abstract}

Keywords : LBW infants; implementation of Kangaroo Mother Care at home; weight gain. 


\section{LATAR BELAKANG}

Hingga saat ini Bayi Berat Lahir Rendah (BBLR) merupakan masalah di berbagai bagian dunia karena merupakan penyebab kesakitan dan kematian pada masa bayi baru lahir. Angka kesakitan dan kematian pada bayi BBLR lebih tinggi tiga sampai empat kali dari pada bayi-bayi dengan berat lahir normal (Maryunani, 2013). Indonesia memiliki angka kejadian BBLR sekitar $27 \%$ (Wijayanegara et al, 2009) sebagai salah satu negara Asia dengan jumlah kematian bayi tertinggi di ASEAN.Bayi berat lahir rendah (BBLR) yang disebut juga low birth weight infant (LBW Infant) ialah bayi baru lahir dengan berat badan kurang dari 2.500 gram.

Angka kematian bayi (AKB) di Indonesia tahun 2012 adalah 32 dari 1.000 kelahiran hidup atau tercatat sebanyak 146.739 kejadian, dimana $50 \%$ nya terjadi di lima propinsi, yaitu: Jawa Barat, Jawa Tengah, Jawa Timur, Sumatra Utara dan Banten. Jawa Barat dilaporkan menduduki peringkat pertama, yaitu 16\% (SDKI, 2012), Hal ini masih cukup jauh dibandingkan target Millenium Development Goals (MDGs) ke-4 yaitu menurunkan angka kematian bayi yaitu 23 per 100 ribu kelahiran hidup,dan dilanjutkan dengan SDG 2015-2030 untuk tujuan ke-11 butir keenam, yaitu secara signifikan mengurangi jumlah kematian dan jumlah orang yang kena dampak, dengan fokus pada melindungi orang miskin dan orang-orang dalam situasi rentan (Rohim, 2015).

Bayi Berat Lahir Rendah (BBLR) membutuhkan bantuan dan waktu penyesuaian kehidupan. Mereka juga memerlukan bantuan untuk tetap hangat dan mendapatkan ASI yang cukup untuk tumbuh. Satu cara untuk menolong bayi mendapatkan kebutuhan ini adalah menjaga bayi untuk tetap kontak kulit dengan kulit ibunya. Perawatan metode kanguru adalah suatu cara agar BBLR terpenuhi kebutuhan khusus mereka terutama dalam mempertahankan kehangatan suhu tubuh (Kemenkes RI, 2011).

\section{METODE}

Penelitian ini dilaksanakan menggunakan metode deskriptif kuantitatif.Data dikumpulkandan kemudian dianalisa dengan menggunakan uji statistik korelasi Spearman's rho. Populasi penelitian ini adalah semua ibu dengan bayi BBLR yang telah pulang dari RSUD Soreang dan telah diizinkan pulang sebelum PMK dapat dinilai efektifitasnya. Metode sampling yang digunakan adalah non probability sampling dengan jumlah sampel adalah 30 orang ibu beserta bayinya.

\section{HASIL}

Tabel 1 menunjukkan bahwa karakteristik usia ibu yang melahirkan BBLR di RSUD Soreang pada periode Mei-Juli 2016 adalah kelompok usia wanita yang melahirkan BBLR terbanyak adalah kelompok usia wanita subur yaitu 21-35 tahun sebanyak 16 orang $(53,3 \%)$, dengan usia gestasi paling banyak pada kelompok usia gestasi 34-36 minggu yaitu 12 orang (40\%). Sedangkan tingkat pendidikan ibu yang terbanyak adalah tingkat pendidikan menengah yaitu 18 orang (60\%) dan ibu yang tidak bekerja jauh lebih banyak yaitu 29 orang $(96,7 \%)$ bila di banding dengan ibu yang bekerja.

Tabel 1 juga menunjukkan bahwa berat badan BBLR yang lahir di RSUD Soreang periode Mei-Juli 2016 paling banyak jumlahnya pada kelompok berat badan lahir di atas atau sama dengan 2000 gram yaitu sebanyak 25 bayi $(83,3 \%)$ dan setelah dilakukan evaluasi di rumah kelompok BBLR (BB 1500-2499 gram) menunjukkan jumlah yang paling banyak yaitu 17 bayi (56,7\%), sedangkan usia bayi saat dilakukan evaluasi di rumah menunjukkan kelompok usia lebih dari 4 minggu telah mendominasi dengan jumlah 13 bayi $(43,4 \%)$. 
Tabel 1.Data usia ibu, usia gestasi, pendidikan ibu, pekerjaan ibu, berat lahir bayi dan berat bayi dan usia bayi

\begin{tabular}{ccc}
\hline Karakteristik & Frekuensi & Persentase (\%) \\
\hline Usia Ibu & & \\
$<21$ tahun & 8 & 26,7 \\
$21-35$ tahun & 16 & 53,3 \\
$>35$ tahun & 6 & 20 \\
\hline Total & $\mathbf{3 0}$ & 100 \\
\hline Usia Gestasi & 7 & 23,3 \\
$30-33$ minggu & 12 & 40 \\
$34-36$ minggu & 11 & 36,7 \\
37-39 minggu & $\mathbf{3 0}$ & $\mathbf{1 0 0}$ \\
\hline Total & & \\
Pendidikan Ibu & 10 & 33,3 \\
Rendah & 18 & 60 \\
Menengah & 2 & 6,7 \\
\hline Tinggi & $\mathbf{3 0}$ & $\mathbf{1 0 0}$ \\
\hline Total & & \\
\hline Pekerjaan Ibu & 29 & 96,7 \\
Tidak bekerja & 1 & 3,3 \\
Bekerja & $\mathbf{3 0}$ & $\mathbf{1 0 0}$ \\
\hline Total & & \\
\hline Karakteristik & 5 & 16,7 \\
\hline Berat Lahir Bayi & 25 & 83,3 \\
<2000 gram & $\mathbf{3 0}$ & $\mathbf{1 0 0}$ \\
\hline$\geq 2000$ gram & &
\end{tabular}

Berat Bayi Saat Dilakukan

Evaluasi

$\begin{array}{lll}\text { BBLSR } & 1 & 3,3\end{array}$

$\begin{array}{llr}\text { BBLR } & 17 & 56,7\end{array}$

\begin{tabular}{ccc} 
Normal & 12 & 40 \\
\hline Total & 30 & 100 \\
\hline
\end{tabular}

Usia Bayi Saat Evaluasi

$<2$ minggu $\quad 7 \quad 23,3$

$\begin{array}{lll}2-4 \text { minggu } & 10 & 33,3\end{array}$

$>4$ minggu 13

Total 30

Tabel 2 dapat dilihat bahwa dalam hal-hal orang (60\%), dalam hal "merespon hypothermi yang perlu dijalankan untuk mendukung pelaksanaan PMK di rumah oleh ibu pasca rawat inap di RSUD Soreang periode Mei-Juli 2016 tentang "kemauan ibu melakukan PMK di rumah didapati lebih banyak pada ibu yang tidak melaksanakan PMK di rumah" dengan jumlah 27 orang (90\%), dan "keluarga yang tidak mendukung pelaksanaan PMK di rumah" juga lebih banyak berjumlah 27 keluarga (90\%). Dalam hal "ibu yang tidak dapat memandikan bayi" dan "menjaga bayi" didominasi oleh ibu yang tidak bisa merespon bayi hypothermi sebanyak 20 orang $(66,7 \%)$, juga dalam hal "Memberikan ASI yang benar" lebih banyak ibu yang tidak dapat memberikan ASI dengan benar dengan jumlah 18 orang (60\%). Jumlah "ibu yang tidak membawa BBLR kontrol sesuai jadwal" lebih banyak dengan jumlah 21 orang (70\%), dimana sama banyaknya dengan "ibu yang tidak mengerti tanda bayi dalam bahaya" yaitu sebanyak 21 orang (70\%).

kehangatan bayi" berjumlah lebih banyak yaitu 18 
Tabel2 Data pelaksanaan PMK di rumah, keluarga membantu pelaksanaan PMK dapat memandikan dan menjaga kehangatan bayi, dapat merespon bayi hypotermi, memberi ASI dengan benar, kontrol pada waktunya, dan mengerti kondisi bayi dalam bahaya

\begin{tabular}{|c|c|c|}
\hline Karakteristik Ibu & Frekuensi & Persentase (\%) \\
\hline \multicolumn{3}{|c|}{ Dapat melakukan PMK Mandiri } \\
\hline \multicolumn{3}{|c|}{ Tidak } \\
\hline \multirow[t]{2}{*}{ Ya } & 27 & 90 \\
\hline & 3 & 10 \\
\hline Total & 30 & 100 \\
\hline \multicolumn{3}{|l|}{ Keluarga Membantu } \\
\hline \multicolumn{3}{|l|}{ Pelaksanaan PMK } \\
\hline Tidak & 27 & 90 \\
\hline $\mathrm{Ya}$ & 3 & 10 \\
\hline Total & 30 & 100 \\
\hline \multicolumn{3}{|l|}{ Dapat Memandikan dan } \\
\hline \multicolumn{3}{|l|}{ Menjaga Kehangatan Bayi } \\
\hline \multicolumn{3}{|l|}{ Tidak } \\
\hline \multirow[t]{2}{*}{ Ya } & 18 & 60 \\
\hline & 12 & 40 \\
\hline Total & 30 & 100 \\
\hline \multicolumn{3}{|l|}{ Dapat Merespon Bayi } \\
\hline \multicolumn{3}{|l|}{ Hypotermi } \\
\hline Tidak & 20 & 66,7 \\
\hline $\mathrm{Ya}$ & 10 & 33,3 \\
\hline Total & 30 & 100 \\
\hline \multicolumn{3}{|l|}{ Memberi ASI Dengan Benar } \\
\hline \multicolumn{3}{|c|}{ Tidak } \\
\hline \multirow[t]{2}{*}{$\mathrm{Ya}$} & 18 & 60 \\
\hline & 12 & 40 \\
\hline Total & 30 & 100 \\
\hline \multicolumn{3}{|l|}{ Kontrol Pada Waktunya } \\
\hline \multicolumn{3}{|l|}{ Tidak } \\
\hline \multirow[t]{2}{*}{ Ya } & 21 & 70 \\
\hline & 9 & 30 \\
\hline Total & 30 & 100 \\
\hline \multicolumn{3}{|c|}{ Mengerti Bayi Dalam Bahaya } \\
\hline \multirow{3}{*}{$\begin{array}{c}\text { Tidak } \\
\text { Ya }\end{array}$} & & \\
\hline & 21 & 70 \\
\hline & 9 & 30 \\
\hline Total & 30 & 100 \\
\hline \multicolumn{3}{|l|}{$\begin{array}{c}\text { Kategori Kenaikan Berat } \\
\text { Badan Bayi }\end{array}$} \\
\hline Kurang dari standar & 19 & 63,4 \\
\hline Standar $=15 \mathrm{gr} / \mathrm{KgBB} / \mathrm{hr}$ & 1 & 3,3 \\
\hline Melebihi standar & 10 & 33,3 \\
\hline Total & 30 & 100 \\
\hline
\end{tabular}

Tabel 2 bagian akhirmenunjukkan bahwa kenaikan berat badan bayi dalam program pelaksanaan PMK di rumah oleh ibu pasca rawat inap di RSUD Soreang didominasi dengan kenaikan berat badan bayi yang kurang dari standar sebanyak 19 bayi $(63,4 \%)$. 
Tabel 3.Hubungan Antara Pelaksanaan Perawatan Metode Kanguru di Rumah Dengan Peningkatan Berat Badan Bayi Berat Lahir Rendah

\begin{tabular}{lcccccc}
\hline $\begin{array}{l}\text { Pelaksanakan } \\
\text { PMK di Rumah }\end{array}$ & $\begin{array}{c}\text { Kurang dari } \\
\text { standar }\end{array}$ & $\begin{array}{c}\text { Standar }=15 \\
\text { gr/KgBB/hr }\end{array}$ & $\begin{array}{c}\text { Melebihi } \\
\text { Standar }\end{array}$ & $\mathbf{n}$ & $\boldsymbol{p}$ Value & Korelasi \\
\hline $\begin{array}{l}\text { Tidak } \\
\text { melaksanakan }\end{array}$ & 18 & 1 & 8 & 27 & & \\
$\begin{array}{l}\text { Melaksanakan } \\
\text { sebagian }\end{array}$ & 0 & 1 & 0 & 1 & 0,046 & $36,7 \%$ \\
$\begin{array}{l}\text { Melaksanakan } \\
\text { penuh }\end{array}$ & 0 & 0 & 2 & 2 & & \\
\hline
\end{tabular}

Tabel 3 menunjukkan bahwa dari 30 responden terdapat 27 orang (90\%) yang tidak melakukan PMK di rumah, ada 3 orang (10\%) yang melakukan PMK dengan karakteristik: (3,3\%) melakukan PMK sebagian dan (6,7\%) melakukan PMK secara penuh. Dari jumlah ibu yang tidak melakukan PMK ada 18 bayi $(66,7 \%)$ mengalami peningkatan BB kurang dari standar, $3,7 \%$ bayi mengalami peningkatan BB sesuai standar yaitu 15 gram/KgBB/hari, dan ada 29,6\% bayi mengalami peningkatan BB melebihi standar. Sedangkan pada ibu yang melakukan PMK 100\% bayi mengalami peningkatan BB sesuai dengan standar. Pada kelompok ibu yang melakukan PMK penuh ada $100 \%$ bayi mengalami peningkatan BB melebihi standar. Dengan demikian, dari 30 BBLR yang dievaluasi terdapat $63,3 \%$ bayi yang mengalami peningkatan BB kurang dari standar, ada 6,6\% yang mengalami peningkatan $\mathrm{BB}$ standar, dan $33,4 \%$ yang mengalami peningkatan $B B$ melebihi standar. Dapat disimpulkan bahwa ada hubungan sebesar $36,7 \%$ antara pelaksanaan PMK di rumah dengan peningkatan berat badan BBLR dengan $p$ value $=0,046$.

\section{PEMBAHASAN}

Dari tujuh butir pendukung penerapan PMK didapati 90\% yang tidak memberikan bantuan kepada ibu dalam melaksanakan PMK di rumah dengan alasan tidak mengerti, didapati hanya 10\% yang membantu ibu dalam melaksanakan PMK di rumah. Ada 18 ibu (60\%) yang tidak dapat memandikan dan menjaga kehangatan bayi dengan alasan belum berani memandikan bayi karena bayi masih sangat kecil, sementara ada 12 ibu (40\%) yang mampu melakukannya. Ibu yang tidak dapat merespons bayi hypotermi berjumlah 20 orang $(66,7 \%)$ dengan alasan kurang mengetahui kebutuhan BBLR akan kehangatan dengan menidurkan bayi pada kasur di atas lantai dengan posisi dekat dengan pintu ruang tamu yang sering terbuka tertutup dengan tanpa lampu penghangat, dan ada 10 orang $(33,3 \%)$ yang dapat menjaga kehangatan dengan cara membedong bayi, melindungi bayi dari hal-hal yang mendatangkan kondisi kehilangan panas tubuh dan memasang lampu penghangat ataupun botol berisi air panas di sekitar bayi ditidurkan. Semua BBLR memerlukan ASI eksklusif, dan yang melaksanakannya ada 12 ibu (40\%) bagi BBLR-nya, namun demikian ada $18 \mathrm{ibu}$ (60\%) yang memberikan ASI ditambah dengan susu formula, bahkan ada BBLR yang hanya diberi susu formula saja. Setiap BBLR setelah dibawa pulang memiliki jadwal untuk kontrol ke bidan, dokter, ataupun rumah sakit sesuai dengan waktu yang telah ditentukan. BBLR yang tidak dibawa ibu untuk kontrol sesuai jadwal ada 21 bayi (70\%) dengan alasan tidak ada biaya, tidak mempunyai kendaraan pribadi, dan tempat tinggal jauh dari fasilitas kesehatan dimana saat peneliti berkunjung ke rumah responden ada yang jarak tempuhnya $35 \mathrm{~km}$ yang rata-rata kendaraan tidak bisa menjangkau rumah mereka sehingga harus 
berjalan kaki sebelum dan setelah naik kendaraan umum, sedangkan 9 Bayi (30\%) dibawa kontrol oleh ibunya sesuai dengan waktu yang ditentukan. Bayi BBLR sangat rentan terhadap hal-hal yang membahayakan tubuhnya. Dari 30 responden lebih banyak tidak mengetahui tanda bahaya bagi bayi, berjumlah 21 orang (70\%) dengan alasan belum punya pengalaman karena masih baru melahirkan anak pertama, disatu sisi hanya ada 9 orang (30\%) yang mengerti tanda bahaya bagi bayi seperti: demam, diare, muntah, batuk, kejang, dan sesak napas.

Merujuk pada hasil evaluasi yang dilakukan pada penelitian ini didapati mayoritas ibu $(96,7 \%)$ memiliki karakteristik tidak bekerja, yang berarti memiliki waktu yang cukup banyak untuk melaksanakan PMK di rumah, tetapi kenyataannya hanya $10 \%$ ibu yang melaksanakan PMK, karena tercatat sangat kurang mendapat dukungan dari keluarga, serta kurangnya edukasi tentang PMK bagi ibu yang memiliki BBLR sehingga pelaksanaan PMK mandiri didapati masih rendah. Dari 30 BBLR ada 18 (60\%) yang mengalami penurunan berat badan saat dilakukan evaluasi di rumah dimana berat badan lebih rendah dari berat badan lahir karena masih lebih banyak (70\%) ibu tidak mengerti tanda bayi dalam keadaan bahaya dan $(60 \%)$ ibu yang kurang mengerti bagaimana menjaga kehangatan bayi serta kurang mengerti bagaimana merespon bayi dari hypotermi yang dibuktikan saat evaluasi dilakukan, suhu tubuh bayi mayoritas $<37^{\circ} \mathrm{C}$ bahkan ada yang $<36^{\circ} \mathrm{C}$, bayi ditidurkan di kasur di ruang tamu dan dekat pintu utama, dimana angin lebih berhembus membuat bayi kehilangan panas tubuhnya, ditambah dengan kurangnya penghangat seperti pemakaian lampu pijar untuk menghangatkan ruangan bayi. Hal lain yang berhubungan dengan penurunan BB BBLR adalah tentang pemberian nutrisi dimana $60 \%$ ibu tidak memberikan ASI dengan benar dengan mengombinasikan dengan susu formula, bahkan murni memberikan susu formula. Yang lebih menarik lagi adalah, didapati ibu yang memberikan suplemen untuk BBLR berupa vitamin penambah selera makan anak-anak. Bila melihat banyaknyanya ibu yang tidak membawa bayinya kontrol sesuai dengan waktu yang ditentukan karena tempat tinggal yang jauh dari fasilitas kesehatan serta kurangnya sarana transportasi dimana ibu harus berjalan kaki yang cukup jauh untuk mendapatkan kendaraan umum, dan juga faktor finansial yang kurang baik karena banyak dari keluarga buruh harian.

Berdasarkan pedoman yang diterbitkan oleh Organisasi Kesehatan Dunia (WHO, 2003) ibu yang melakukan PMK di rumah harus mengetahui hal-hal seperti: 1) Melakukan kontak kulit langsung dengan bayi sampai bayi menunjukkan rasa ketidaknyamanan. 2) Cara memakaikan pakaian bayi saat bayi tidak dalam kondisi kanguru, untuk menjaganya bayi tetap hangat. 3) Cara memandikan bayi dan menjaga kehangatannya setelah mandi. 4) Cara menanggapi kebutuhan bayi, seperti meningkatkan lama kontak kulit langsung ibu-bayi jika tangan atau kaki bayi menjadi dingin, atau pada suhu yang dingin di malam hari. 5) Cara menyusui bayi selama siang dan malam berdasarkan petunjuk yang benar yang telah diberikan. 6) Mengetahuiwaktu dan tempat pelayanan kesehatan bagi bayi untuk kunjungan follow up. 7) Mengenali bayi dalam tanda-tanda bahaya serta mencari pertolongan awal bila tanda bahaya muncul, dan 8) Mengetahuiwaktu yang tepat untuk melakukanpenyapihan bayi dari PMK.

Ibu sebaiknya kembali ke rumah sakit atau tempat pelayanan yang tepat bila bayi mengalami hal seperti berikut: 1) Berhenti minum, tidak bisa minum dengan baik, atau muntah, 2) Menjadi gelisah, mudah terangsang, letargi, lesu atau tidak sadarkan diri: demam, suhu badan diatas $37,5^{\circ} \mathrm{C}$, 3) Dingin (hipotermi: suhu badan dibawah $36,5^{\circ} \mathrm{C}$ ) walau telah diupayakan penghatan ulang, 4) Kejang, 5) Mengalami kesulitan bernafas, 6) Diare, dan 7) Menunjukkan gejala lain yang mengkhawatirkan.

Dapat dirangkuman bahwa BBLR memerlukan PMK untuk mendapatkan kehangatan dari ibunya yang salah satu tujuannya 
untuk meningkatkan berat badan BBLR dengan lebih baik. Pada kenyataannya baru 10\% ibu yang melakukan PMK dan sebagian besar (90\%) ibu masih belum mengerti manfaat PMK sehingga tidak ada keinginan untuk melakukan PMK bagi BBLR-nya di rumah, dan belum bisa melakukan perawatan penunjang seperti memberikan ASI eksklusif, menjaga kehangatan bayi, membawa bayi kontrol sesuai dengan waktu yang ditentukan, dan kurang mengerti tanda bayi dalam keadaan bahaya.

Bertalian dengan kenaikan berat badan $\mathrm{BBLR}$, Penelitian ini sejalan dengan penelitian yang serupa yang dilakukan di Rumah Sakit PKU Muhammadiyah Gombong oleh Priyanti Mutoharoh pada tahun 2009 tentang pengaruh PMK terhadap kenaikan berat badan BBLR dengan Quasi Eksperimen yang bertujuan untuk melihat perbedaan peningkatan berat badan BBLR antara yang dilakukan PMK dan yang tidak dilakukan PMK. Sampel berjumlah 28 BBLR yang dibagi menjadi dua kelompok, yaitu kelompok control dan kelompok yang menerima perlakuan. Dari penelitian tersebut didapatkan hasil yang signifikan dengan $p$ value $<0,05$ dimana kelompok yang dilakukan PMK mengalami kenaikan BB sebesar $1.257,50$ gram, sedangkan kelompok yang tidak dilakukan PMK mengalami kenaikan lebih rendah yaitu sebesar 1.071,43 dengan selisih 186,07 gram.

Sesuai dengan teori Maryunani (2013) menuliskan bahwa manfaat PMK bagi ibu adalah: untuk meningkatkan berat badan bayi prematur atau berat badan lahir rendah, dengan cara: menstabilkan denyut jantung, pola pernapasan dan saturasi oksigen, memberikan kehangatan pada bayi, meningkatkan durasi tidur, mengurangi tangisan bayi dan kebutuhan kalori, mempercepat peningkatan berat badan dan perkembangan otak, meningkatkan hubungan emosional ibu dan bayi, dan meningkatkan keberhasilan dan memperlama durasi menyusui.

Perawatan metode kanguru adalah ikatan untuk meningkatkan kasih sayang antara orang tua dengan bayi dengan cara menempatkan bayi prematur pada dada orangtua. Biasanya bayi tidak menggunakan pakaian tetapi menggunakan popok saja (Gomella, 2009). Sedangkan menurut Efendi (2012) menjelaskan bahwa perawatan metode kanguru (Kangaroo Mother Care) atau disebut juga asuhan kontak kulit dengan kulit (skin to skin contact) merupakan metode khusus asuhan bagi bayi berat lahir rendah atau bayi prematur. Bayi yang menerima PMK intermiten memiliki kontak kulit langsung dengan ibu dimana kontak kulit ini (skin to skin) dapat memberikan efek yang menenangkan bayi sehingga bayi akan mempunyai waktu tidur lebih lama, bayi dapat mempertahankan suhu tubuhnya sehingga energi yang dimiliki tidak digunakan untuk menghasilkan panas/untuk mempertahankan kehangatan tubuh sehingga berat badan meningkat dengan cepat.

Suradi et al (2008) menuliskan bahwaada beberapa indikator didalam memonitor pertumbuhan bayi, salah satunya adalah berat badan. Bayi yang kecil biasanya akan mengalami penurunan berat segera setelah lahir. Penurunan berat hingga $10 \%$ pada beberapa hari pertama masih dapat dikatakan wajar. Setelah itu berat badannya akan mulai bertambah saat bayi berusia 7 sampai 14 hari setelah kelahiran, dan akan terus bertambah. Penurunan berat pada periode ini tidak bisa dibiarkan dan harus diperhatikan. Pertambahan berat badan yang baik dianggap sebagai indikator kesehatan yang baik, bila terjadi penurunan berat badan maka dianggap sebagai masalah yang serius. Tidak ada batasan tingginya, tetapi ada batasan minimalnya, yaitu tidak kurang dari 15 gram $/ \mathrm{kgBB} /$ hari.

Secara jelas terlihat bahwa pelaksanaan PMK di rumah masih minimal.Didapati ibu yang melakukan PMK hanya sebagian dan ada yang melakukannya penuh.Implikasi yang jelas bahwa BBLR yang memperoleh PMK sebagian mengalami peningkatan BB sesuai standar yaitu 15 gram/KgBB/hari, sedangkan BBLR yang dilakukan PMK penuh mengalami peningkatan berat badan melebihi standar, sedangkan bayi yang tidak dilakukan PMK sebagian besar mengalami 
penurunan BB dari berat badan saat lahir, bahkan ada dari BBLR menjadi BBLSR.

Selaras dengan teori keperawatan Parentchild interaction yang di kembangkan oleh Kathryne Barnard (Tomey \& Alligood, 2006) dijelaskan bahwa terjadi interaksi antara lingkungan, bayi, dan ibu sebagai pengasuh, dimana lingkungan bayi berupa material maupun manusia sebagai support system mendukung hubungan antara ibu dan bayi. Saat dilakukan PMK terjadi hubungan yang sangat erat antara ibu dan bayi dimana bayi memberikan isyarat yang jelas seperti: menangis, gelisah, rewel yang menggambarkan bayi memerlukan nutrisi, kenyamanan, kehangatan, perhatian dari pengasuhnya. Disini ibu memiliki sensitifitas terhadap isyarat yang diberikan bayi sehingga ibu memperhatikan dan berekasi dengan memberikan kenyamanan, menggendong, memeluk, memberikan ASI-nya sehingga bayi merasa kenyang, hangat (suhu tubuh stabil) respirasi dan detak jantung normal, nyaman, durasi tidur lebih lama serta tidak stress, dimana energy yang didapat dan dimiliki bayi tidak terbuang untuk menimbulkan panas tetapi energy tersebut akan terpakai untuk meningkatkan berat badan, sehingga berat badan BBLR meningkat lebih baik dan cepat, dan ibu merasa tenang, hubungan emosional semakin baik, puas, bangga, serta lebih percaya diri dalam merawat bayinya.

\section{KESIMPULAN}

Berdasarkan hasil penelitian dapat disimpulkan bahwa Perawatan Metode Kanguru (PMK) di rumah oleh ibu pada BBLR pasca rawat inap sudah dilaksanakan namun masih minimal. Kondisi tersebut karena edukasi yang belum diberikan secara optimal sehingga ibu tidak mengerti perlunya melakukan PMK bagi bayinya.Rasio perawat dengan jumlah pasien yang dilayanidi ruang perinatology menjadi kendala dalam pemberian edukasi PMK.

Pelaksanaan PMK di rumah yang masih dalam kategori minimalpun membuktikan sangat efektif dalam meningkatkan berat badan BBLR sesuai standar sebesar 33,3\%, dan melebihi standar sebesar $66,7 \%$. Data dalam penelitian ini menunjukkan bahwa terdapat hubungan yang signifikan antara pelaksanaan PMK di rumah dengan peningkatan berat badan BBLR dengan $p$ value $=0,046$.

\section{REFERENSI}

Efendi, S.H. (2012). SPO perawatan metode Kanguru.http://dadangsjarif's.wordpress.com/ lain.Diperoleh tanggal 12 Maret 2016.

Gomella, T.L., Cunningham, M.D. \& Eyal, F.G. (2009).Neonatology: Management, procedures, on-call problems, diseases, and drugs. (Sixth edition). New York: McGraw-Hill Medical

Kemenkes RI. (2011).Pelayanan kesehatan neonatal esensial: Pedoman teknis pelayanan kesehatan dasar.(Edisi revisi). Jakarta:Depkes.

Lowson, K., et al. (2015). The economic benefits of increasing kangaroo skin-toskin care and breastfeeding in neonatal units: Analysis of pragmatic intervension in clinical practice. International Breastfeeding Journal. (DOI 10.1.1186/s13006-015-0035-8), 2-10.

Maryunani, A. (2013). Asuhan bayi dengan berat badan lahir rendah. Jakarta: Trans Info Media.

Rohim, M. (2015) Membandingkan sdgs dan mdgs. http://citiscope.org/story/2014/comparin g-mdgs-and-sdgs. Diperoleh tanggal 26 April 2016.

Samra, N.M. (2013). Effect of kangaroo mother care on weight gain of low birth weight neonates with delayed weight gain.J Perinat Educ (doi: 10.1891/1058-1243.22.4.149). 18. 
Silvia, Putri, Y.R. \& Gusnila, E., (2014).Pengaruh perawatan metode kanguru terhadap perubahan berat badan bayi lahir rendah.Jurnal IPTEK terapan9 (1), 1-3.

Suradi, R., Pratomo, H., Marnoto, B.W., dan Sidi, I.P.S.(2008). Perawatan bayi berat lahir rendah dengan metode kanguru.Cetakan ke2. Jakarta: Perinasia.

Survei Demografi dan Kesehatan Indonesia.(2012). Kajian angka kematian bayi dan balita menurut survei demografi dan kesehatan Indonesia 2002-2012 \& sensus penduduk 2010. Direktorat Jenderal Bina Graha.
Tomey, A.M. dan Alligood, M.R. (2006). Nursing theory: Utilization \& application. (Third edition). USA: Mosby Elsevier.

WHO. (2003). Kangaroo Mother Care: A Practical guide. Geneva: Department of Reproductive Health and Research.

Wijayanegara,H. Et al. 2009. Prematuritas . Bandung: Penerbit Refika Aditama 